\title{
A Sphinx with a Riddle: The Political Thought and Constitutionalism of Sir George Grey
}

\section{BERNARD CADOGAN}

In October 1865, Napoleon III and Bismarck took a holiday together at Biarritz. When they weren't playing in the sand, or walking the beach with the imperial dog 'Nero', or lying in deck-chairs, drinking champagne and smoking cigars, these bloody-minded men were discussing Prussia's coming war with Austria, for which Bismarck was seeking French neutrality. The emperor gave the go-ahead, strangely demanding nothing in return, in response to which Bismarck remarked that Napoleon III was a 'Sphinx without a Riddle'.

Sir George Grey was also a Second Empire-era 'sphinx'. Governor of South Australia 1841-45, of New Zealand 1845-53, of the Cape Colony and High Commissioner for southern Africa 1854-61, Governor of New Zealand again 1861-68, premier of this country 1877-79, Superintendent of the Auckland Province 1875-76 and a Member of the House of Representatives between $1875-95$, Grey has also had a Sphinx effect on the historiography relating to him. He has not only tantalized and fascinated and repelled, but as Governor of British Gondwanaland, he has as many historiographies as he had nations to rule.

I would hope that my work on Grey is a contribution towards the history of New Zealand (and colonial) political ideas. Abominable man that he was in many respects, he was nonetheless an intellectual in politics, perhaps resembling more Geoffrey Palmer in mental habits than Bernard Freyberg. I regret to say that there has been a trend in some quarters to deny the existence of significant persistent trends of political thought in New Zealand. Yet we may only sustain the Treaty of Waitangi project for New Zealand if we do not denigrate the electorate's capacity or down-grade our own capabilities at handling political thought. Grey's career has left rich and radioactive trace elements for better and worse in New Zealand, Australia and South Africa. In this respect he provides us with creative if sobering and saddening opportunities to recover surprisingly potent traditions and intellectual ecosystems.

Now to review the historiography:

In South African historiography, Grey has gone from being the exemplary racial liberal to a deliberate genocidal monster, the perpetrator of the first 
great British genocide in Africa. Jeff Peires, Clifton Crais, and Mahmood Mamdani are historians who comment on the Xhosa Prophesy, cattle-killing and famine in this sombre light. ${ }^{1}$ I believe that we must indeed seek the origins of the Waikato War in the Eastern Cape just five years before. A liberal Afrikaner, Cornelius de Kieweit, has shown the best intellectual grip on Grey's policy of anyone ever. I would argue that his exposition of the South African frontiers as an emerging system demonstrates Grey best as a calm, planning, conniving and systematic intelligence. The weakness of South African historiography on Grey, for all the calamitous events of the Xhosa famine, is that it has never been concerned to understand Grey's other colonial postings or the context of the Colonial Service, nor has it managed to get his ideas right. Jeff Peires for example has proposed the chimaera of a Carlylean-Utilitarian Grey, the combination of which never existed in anyone.

In Australia, Grey had been the youngest and least successful of the leaders of the main exploring expeditions, but had pulled off an ethnographic coup, defining matrilineal totem-like systems in aboriginal societies. The Australian Grey is variously the explorer or ethnographer - still a current source for aboriginal linguistics - or else Sir Harry Parkes' opponent at the Federation Conference in Sydney of 1891. In so far as there is an Australian image of Grey, it was set by Charles Manning Clark in his History of Australia, in which Grey features as a man tormented by ' $a$ vaudeville of devils' ${ }^{2}$ The most significant work on him though was the academic biography by George Cockburn Henderson in 1907. Cockburn founded the academic study of Grey, the historiography of Fiji, and began the Australian interest in Italian historiography. ${ }^{3}$

It would be going too far to say that Grey has compelled Australian interest. Yet he has the Faustian reach and range of the self-punishing and demonic Australian Romantic. He could feature as a tormented figure in a Nolan painting, or Porter poem. He first appears in Manning Clark's History of Australia barely recognizable as a human being on the outskirts of Perth.

This brings me to New Zealand historiography, to which he himself contributed immensely. In my lifetime Grey has gone from being the Agricola Grey, as in Tacitus' biography of the Roman Governor of Britannia, from the 'Good Governor Grey', whom W.P. Reeves considered was New Zealand's Jefferson, ${ }^{4}$ to a Machiavellian 'Monster in the Palace' in McLintock's Crown Colony Government, ${ }^{5}$ to a liar and deceiver, and in Dalton's most negative assessment of all, to an incompetent autocrat who went about covering up his mistakes. ${ }^{6}$ The popular interest in Grey is much the same as it is in South Africa: Grey's sexuality, contradictory character, yet evident high culture, intellect and power-hunger grab the imagination. 
The thrust of recent New Zealand writing is quite the converse of the South African - it seeks a more 'humane' Grey, as white New Zealand seeks to smooth the pillow of its historical nightmare.

The British have of course dropped Grey, and don't know what to say about someone like that. There is a case for a unifying 'Empire' study of Grey that would see him as 'British', and I am pursuing this elsewhere.? That said, there is also a case for an Irish Grey. Not only were his parents Irish Protestants, he served in the 83rd Foot suppressing insurrection in Ireland during the Tithe War, then later influenced the Home Rule movement with his constitutional proposals for Home Rule. Ireland is his imperial groundzero: it is also the ground zero of The Faerie Queene of Edmund Spenser which Grey read, in anticipation of our twenty-first-century readings, as a colonizing epic, an English Protestant epic.

We have focused too much on Grey's character flaws and on sexual titillations and the like. We are not in a position to psycho-analyse such a contradictory personality. He is long dead and we are not clinicians. Moreover, certain disorders might be of an age or of a culture. We don't know the psycho-somatic implications of his mental conditions. He was a gravely wounded man, who seems to have had allergies, sensitive lungs or a compromised immune system. He found English winters brutal. Nevertheless that rickety gate hung on until age 86 , in good mental health until just before he turned 84 . That was good going for someone who lived at a time when the average life expectancy was 40 years when he was born and 51 years for males when he died. With modern medicine one could imagine his centennial party.

What we can focus on is his mind and his policy. New Zealand badly needs a history of political ideas, particularly if it wishes to sustain the Treaty of Waitangi project in both the judiciary and in public policy. David Hamer, Mark Francis and Matthew Palmer ${ }^{8}$ have been simply wrong to deny or dismiss the operation of traditions and trends of political ideas in New Zealand, or to dismiss New Zealanders as merely a pragmatic bunch, without investigating what an informed pragmatism might be. The claim that 'New Zealanders don't do ideas' is a myth.

Grey was a soldier savant, who manifested an intellectual formation that can be described as:

1. Harringtonian: he was an admirer of James Harrington's Oceana and a member of the neo-Harringtonian tradition

2. Liberal Anglican and eventually Unitarian and Massachusetts Transcendentalist

3. Prichardian, monogenist ethnographer who became a social evolutionist: as in the theories of James Cowles Prichard (1786-1848) 
4. Blumenbachian racialist: as in the ideas of Johann Friedrich Blumenbach (1752-1840)

5. Jominian military strategist: as in the theories and military thought of Antoine-Henri Jomini (1779-1869)

6. Physiocratic to Sismondian in his anti-classical Political Economy: a Sismondean of the school of Jean-Charles Leonard Simonde de Sismondi (1773-1842).

Let us start with Harrington. Three classical texts of political thought were written in the English seventeenth century: Thomas Hobbes' Leviathan in 1651, James Harrington's Oceana in 1656 and John Locke's Treatises of Government in 1689. It is simply a quirk of fate that Hobbes and Locke are in the philosophical canon, and Harrington is not.

James Harrington (1611-1677) came from a distinguished Lincolnshire family with access to the Court. He was in fact a Gentleman of the Bedchamber to the captured Charles I. Rather like Grey was to be, Harrington was an anima naturaliter republicana, a natural republican, but he revered the king, just as Grey was to make a religion out of Queen Victoria. With Oceana, Harrington was responding to Hobbes. Hobbes had argued that men in a state of nature compact to enjoy the safety of life and limb and security of property by forming a sovereign political society. He made that synonymous with the absolutist monarchy of the time. Oceana looked on the continent for republican models, not absolutist ones, and applied Venice to England and its shires. Harrington advocated:

1. government by impersonal rotation

2. balloting machines of the Venetian kind. Electoral reform was to be a great concern for Grey

3. property division to ensure a 'commonwealth' of landholders with small- to medium-sized estates. There would be no primogeniture and no estate more remunerative than $£ 2000$ income per annum. This would guarantee a gentry but not an aristocracy of grandees, such as dominated Britain's long eighteenth century. In this we may source Grey's lifelong hostility to great estate owners, whether the hapless 'missionocracy' in 1846, or his campaign against the run-holders in the 1880 s

4. the doctrine of balance and over-balance. This was developed by Bolingbroke to account for the theory of mixed government, which statespersons in this period inherited from Aristotle and Polybius

5. the adoption of the following Machiavellian feature: the necessity for emergency and start-up dictators as in ancient Rome. In other words, 
people like Cromwell or Grey. There was to be however no permanent 'Principe' as Machiavelli intended

6. the necessity for colonization when population and property were 'over-balanced'.

Harrington had served with an English regiment and embassies in the Thirty Years War and had lived in Venice. 'The Serene Republic', a prime destination on the seventeenth- and eighteenth-century Grand Tours of young noblemen, was re-mythologized as a state that might escape history and rise above it. The myth pandered to the vanity of British ruling elites who desired permanence in flux.

What the Harringtonian model explains also is the dictator. Harrington engaged creatively with other thinkers, such as Hobbes and Machiavelli, not polemically. Machiavelli's 'Prince' appears as the nomethetic start-up dictator. In this respect Harrington anticipates the 'Voldemort' of modern constitutional thought on the subject, Carl Schmitt (1888-1985), Hitler's jurist. The dictator exists to found a constitution, and that is basically Grey's selfjustification.

In The Machiavellian Moment, ${ }^{9}$ John Pocock defined a neo-Harringtonian School that made an accommodation with parliamentary government. The School was active largely between the 1690s and 1710s. Henry Neville, who was Harrington's closest associate, lived into this period. Andrew Fletcher of Saltoun, John Trenchard, Thomas Gordon, William Molyneux and Henry St John, Viscount Bolingbroke, were leading members of this group. It would not be accurate to define this school as 'anti-Commerce'. Grey for example was related closely to two significant banking families, the Martins of Martin's Bank (now long merged into Barclays) and Cocks and Biddulph. Grey was all for Commerce and banks so long as they didn't 'corrupt' the public interest. The Jeffersonian line was resistance to Alexander Hamilton's First Bank of the United States.

I propose a later Harringtonian school. Harringtonians most definitely existed in the nineteenth century, largely in Liberal Anglican circles. Grey's mentor Archbishop Whately was one and we know this because he anonymously published a Harringtonian colonial fantasy at the same time Grey was bound for Australia on his first Western Australian expedition in 1837. Whately associated the book with Holland House - the Kensington residence of the Barons Holland, who were the centre of the Whig party and the related families that were its magnates - by saying that 'Lady Mary Fox' had edited it. ${ }^{10}$ Far more fortunate than Grey, the young explorer of this novel discovers a seventeenth-century Anglo-Dutch nation, which had survived a shipwreck off the coast, living in Teutonic harmony and practising racial assimilation and franchise. In this we find not only a precursor of Samuel Butler's 'Erewhon', but also an adamant feature of Grey's South 
African policy: reconciliation between British settlers and Afrikaners and the polity and constitution to bring this about.

Dr Arnold, the famous Arnold of Rugby School, indulged in Harringtonian fantasies. He gave a Commencement Day address at Oxford in 1815, on the eve of Waterloo, in which he argued for colonization - very much frowned upon by Utilitarians - as a remedy for the post-Napoleonic age. ${ }^{11}$ He reiterated the theme in his History of Rome and in the lectures he delivered as Professor of Modern History in 1841..$^{12}$ James Anthony Froude, who was Carlyle's groupie and biographer, adored other dictatorial figures such as Grey and Joseph Chamberlain. He dedicated his globe-trotting review of British settler polities to the Harringtonian theme, by entitling it also Oceana and culminating the work with a Captain Nemo-like visit to Grey on his Kawau Island Valhalla. ${ }^{13}$ The Utilitarian George Cornewall Lewis' 'An Essay on the Government of Dependencies' of 1841 makes an enemy out of the Harringtonians. ${ }^{14}$ Why in 1841 was a book from 1656 such a menace unless it represented a political rival?

Richard Brent has noted that the late regency-early Victorian Whigs of the First Reform Bill era, such as Russell, were on a path from Foxism to moral liberalism. They left behind the mechanized virtue of Harringtonian institutions. ${ }^{15}$ This is not to say that the Court Whigs did not go undergo the same seventeenth-century revival I referred to before, focusing on the personalities and values of the late seventeenth century. Lord John Russell's ideological productions especially indulged in this. Grey was a radical Whig who was never part of Holland House, even though he knew people admitted to it, such as Whately and his chaplain, the Spanish liberal Blanco White. Grey went out to colonize and remained a proponent of government by impersonal rotation and mechanized virtue. He believed it was enough for an institution or practice to correspond to the 'ordinary providence' of God's laws, for it to be efficacious.

To turn to the other intellectual formations: Liberal Anglicans are a well-established formation in the British history of political ideas. They are early nineteenth-century descendents of what Trevor-Roper and Pocock have defined as the latitudinarian, Erasmian, Grotian, and Cambridge Platonist traditions. ${ }^{16}$ In this definition you have their religiosity, their anthropology, their scholarship and esoteric and possible magical interests all wrapped up. They were united by their approval of Bishop Joseph Butler's Analogy of Religion Natural and Revealed, or the Constitution and Course of Nature, of $1736,{ }^{17}$ which was deemed to be a definitive answer to the Deists. Copleston and Whately at Oriel College were the head of the Oxford Liberal Anglicans, while the Cambridge grouping adhered about Whewell. Cambridge Liberal Anglicans such as Julius Charles Hare and John Sterling, about whom Carlyle wrote a life, were near neighbours of Grey's East Sussex family at 
Bodiam. Grey's cousin Sherlock Willis was a Fellow of Oriel, and seems to have been match-maker for Grey's cousin Elizabeth Pope and Whately, and they in turn were the parents of Samuel Butler's aunt.

The Liberal Anglicans were Arminians and from this Arminianism came an anthropology that regarded indigenous peoples in a dismal light. Arminians were moderate and reconstructed Calvinists: unlike Calvin, Arminius had taught that Christ did die for all sinners, and not just for the elect, and that the saints could relapse - whereas Calvin had taught that Grace was irresistible. Yet both Calvin and Arminius were united in their vision of an utterly depraved humanity, corrupted by original sin. 'Savages', according to Whately, were the ultimate and bitter-enders rebels of humanity, who had deformed their own humanity through their persistent revolt. Humanity had two poles: at the bottom were these supposed Yahoos of inhumanity - the equivalent of Mad Max bikie gangs - and at the top, races and people and nations that had remained in touch with divine intelligences (divine revelation or angels) after the banishment from Eden. Once God's ordinary providence took over and human pre-history became history, higher civilizations and higher humans were to lead lesser races to civilization. It is a Tolkienesque world. Everything is either 'Narnia' or Swift's 'Yahoos'. Grey, in Whately's view, was one of these missionary demi-urges. The point at which this vision isn't Tolkienesque lies in Grey's agreement with John Cowles Prichard that humanity had one single origin, not multiple origins. Grey rejected Lord Kames and Sir John Lubbock's theory of 'Polygenism'. Grey had good German - though Carlyle had been largely the major conductor of German civilization to the young Grey. From the German idea of Sturm und Drang Grey adopted the racialist ideas of Johann Friedrich Blumenbach, who believed in the plasticity and not the fixity of races. Grey knew the Scottish geologist Sir Roderick Murchison who had studied under Blumenbach. Culture, then, was the enemy.

The curious thing about this formation held by Grey is that he literally had a Paley's watch experience in the Australian desert. In the Paley's watch scenario, Paley would have us walk in a desert and find a watch. Compared with the environs, you would infer that it was designed. Well then, says Paley, all of nature is like this and just as designed by God. Nonsense, argues Richard Dawkins, a human body is vastly more complicated than a watch and it is the product of evolution by natural selection and self-organization in Nature. Well, Grey inferred from his observation of aboriginal institutions that they were so designed as to permit the survival of aboriginal peoples on a harsh continent and to enable them to live rationally and well, but also prevent them from developing any further, because of the interlocking checks and balances he detected in their culture. God had done this. Divine intelligence had equipped the aborigines with these institutions, enabling 
them to survive until the British were destined by Providence to come and repeal that dispensation. Thus Grey contributed to the myth that Eden had once been located in western Australia, and that the inhabitants were the closest humans to those exiled by the angel with the burning sword.

Grey was stadialist but it would be wrong to think that the standard Scots Enlightenment scheme of a progression from hunters to pastoralists to agriculturalists to urbanites was his scheme or that of the Liberal Anglicans. The 'savage state' was deemed so sunken as to impair human reason and prevent self-progression, which were considered possible at the higher stages. Even Adam Smith doubted that self-progression was possible for 'savages'. ${ }^{18}$ Albert Gallatin noted the extreme difficulty with which American Indians renounced hunting for agriculture. The one instance Gallatin offered of a culture that had managed it, the Chilean Araucanians, was an ominous example, on account of the resistance that these indigenous people had been able to offer the colonizers. ${ }^{19}$ For as Pocock has noted, horticulture was not admitted as a 'stage' in these Eurocentric schemes. ${ }^{20}$ The Liberal Anglicans adhered more to a civic humanist and seventeenth-century model that conflated, as the ancients had, the hunter and the pastoralist. The 'savage' had been defined by the seventeenth-century jurist Hugo Grotius as amentes et insensati (insensate and out of their minds). ${ }^{21}$ While he admitted the Sultan of Johore as a sovereign prince in an international state system, Grotius was an Arminian who condemned the Brazilian tribes to a place off the scale and outside of any Catholic or classical Jus Gentium or Natural Law system. Is it too much to say that Grey did the ethnography for a Liberal Anglican Arminian anthropology in justification of Harringtonian colonizing projects?

I also contend that Grey, like Napoleon III and Bismarck whom we left on their deck-chairs at Biarritz, 'constituted' violence as well as constitutions. Grey conforms to Deleuze and Guattari's description in Milles Plateaux of the military engineer as the exemplary exponent of 'people-catching' nomadic science. ${ }^{22}$ Antoine-Henri Jomini (1779-1869) was another one of Grey's favoured francophone Protestant authors. He left Napoleon's service for the Tzar's in 1813. It was he who came up with the military theory for frontiers that explains Grey's practice - and also de Keiweit's explanation of Grey. In Jomini's theory there were to be no hard and fast frontiers or Hadrian's walls. No armies were to march over like the IXth Legion and expose themselves. Flying columns would awe. A native attack would be admitted and disposed off within the colony. The entire movements of peoples would be treated thus. Indigenous peoples, Grey makes clear in the Port Louis paper, were not to be concentrated on the frontiers but be conducted into the colony and assimilated into it by a managed process. Jomini was long in vogue at a time when Clausewitz - the Prussian solder 
and military theorist who wrote the military classic On War - had just a German-wide reputation. Clausewitz did not explain frontiers, Jomini did. It is no surprise then that the two great nineteenth-century terrestrial empires were Jominian in doctrine: the United States and Russia. Jomini was the Tzar's war-planner. By 1817 he was being translated at West Point. Grey belonged to a small group of military intellectuals in the British Army who considered such military thought. After all the British had defeated Napoleon without it. But Sir Harry Smith and Grey were two governors in South Africa with 'forward' policies who knew their Jomini.

Grey's first constitutional paper, the Port Louis paper, applied all of this thinking in distilled form. He sent this work from Mauritius to Lord John Russell in June 1840. In it he argued against the Buxton Report, the report of the Select Committee of Aboriginal Affairs of 1837. He maintained there were just three racial systems in the British empire over five centuries:

- native protection and segregation

- assimilation

- indirect rule.

The native protection system developed out of Spanish practice, from Philip II's Ordinance on Population and Discoveries of 1573. Its principles were affirmed as British practice by Charles II's Letter to the Council of Foreign Plantations of 1670. It was instituted into a system of government by the Appalachian Proclamation of 1763 and incorporated into the resulting Protectorate. Mark Hickford has written about this, and its consequences for understanding the Treaty of Waitangi in New Zealand, in his outstanding Oxford thesis of 1999..$^{23}$ In Sir William Johnson's system, colonization was forbidden over a proclaimed frontier from the Gulf of Mexico to the Great Lakes. ${ }^{24}$ Traders were forbidden to enter except under licence. Missionaries were forbidden unless the Superintendent approved of them. Periodic treaties were signed to make land available to the great land companies.

This system was opposed by Thomas Jefferson and the Virginian settler interests that he represented. Jefferson promoted assimilation as the policy of the United States. This was a descendant of the policy of Tudor and Jacobean Ireland that you will find in the poet Edmund Spenser's 'A View of the State of Ireland' of $1596 .{ }^{25}$ As Thomas Arnold noted in 1815, this policy had been applied to Virginia as early as $1612 .{ }^{26}$ The Utilitarians and Evangelicals proposed assimilation as a form of legal and economic integration for Indians in British India, in opposition to Sir William Jones' Orientalists. Grey adopted the assimilation position, though he was neither an Evangelical nor a Utilitarian. The Liberal Anglicans had committed themselves to anti-classical economics. William Rees' work From Poverty to Plenty; or, the Labour Question Resolved of $1888^{27}$ is a good source for 
Grey's private economic views. The text conforms to Grey's New Zealand political speeches, and the preface not only dedicates the book to Grey but also acknowledges his influence. Grey was a Physiocrat of the school of Francois de Quesnay and had recycled himself in response to the industrial revolution into a Sismondean, rather like his friend Florence Nightingale. Liberal Anglicans had so little enthusiasm for Boyd Hilton's 'atonement' as a test for Evangelicalism, that they were suspected of Socinianism and of being Unitarians ${ }^{28}$ - which is indeed where Grey moved to in his religious beliefs. He liked the Massachusetts Transcendentalist Dr Theodore Parker.

So the fact that Evangelicals affirmed the 1763 segregation system in the Burton Report of 1837, while proposing integration in India, left it open for a whipper-snapper like Grey to propose a policy of thorough-going assimilation and legal integration. The Port Louis paper is a point by point refutation of the Buxton Report and of the Appalachian policy. The humanitarian voice for assimilation in the era of slave emancipation - for Jefferson was after all a slave owner - had been supplied in the 1760s by Bishop William Warburton of Gloucester. Warburton was an anti-slavery agitator but also an opponent of the Appalachian policy. ${ }^{29} \mathrm{He}$ was also one of those Butlerian Anglicans in the Arminian, Grotian, Erasmian, Latitudinarian descent that Trevor-Roper and Pocock identified. The third racial system identified by Grey was the system of Indirect Rule, which created labour pools for plantations, mines, public works and industry. Sir Henry Sumner Maine theorized a practice that was being carried out by Sir Arthur Gordon and Sir William des Voeux in Fiji, for instance. Indirect Rule became the staple policy of the protectionist twentieth-century British empire, as assimilation has been for the free trade empire, and native protection and segregation had been for the mercantilist empire.

Thus I explain Grey and bring him to the doorstep of his major constitutional activity of the 1840s in New Zealand. For Grey, a settler constitution was also a racial order. The Port Louis paper was the racial policy for which the New Zealand Constitution Act 1852 was supposed to be the constitution. The hall-marks of a Grey constitution, whether proposed for New Zealand (1847-51), Natal (1855), a Southern African Federation (1859) or more broadly speaking Ireland (1869) are:

- a federal system

- elected executive officers at provincial level

- the representation of those officers in central government as virtual 'caciques and caudillos'

- the rotation of ministries in central government

- the executive origination of money bills

- a broadly dispersed property franchise and hostility to what Grey perceived to be monopoly capitalism and an 'Ascendancy' 
- a broad to democratic franchise

- the assimilation of non-settlers into an enracinated, autochthonous settler order, with civil rights

- the necessity of a start-up dictator and the need for some nationbuilding realpolitik

- a capacitarian liberal model that could none the less educate ordinary men and women (for he was an early male feminist) and be operated by people with an average education.

We may find Grey a thoroughly detestable man - although there are always those who find him 'fascinating'. Our business is to show where he was reasonable and unreasonable for his own time, and the consequences for our own. It would be fitting to conclude this search for his sense of himself and his age's yearning for 'the Great Man' with some megalomaniacal hi fi. As the crest of Grey's arms featured a unicorn charging into the sun, I shall conclude with Australian poet Christopher Brennan (1870-1932), whose verse may capture the Romantic mysticism of Grey's generation and his aspirations:

My heart was wandering in the sands, a restless thing, a scorn apart; Love set his fire in my hands, I clasped the flame unto my heart. Surely, I said, my heart shall turn one fierce delight of pointed flame; and in that holocaust shall burn its old unrest and scorn and shame: surely my heart the heavens at last shall storm with fiery orisons, and know, enthroned in the vast, the fervid peace of molten suns.

From 'My heart was wandering in the sands' ${ }^{30}$

1 J.B. Peires, The Dead will Arise: Nongqawuse and the Great Xhosa Cattle-Killing Movement of 1856-57, Bloomington and Indianapolis, 1989; Clifton Crais, The Making of the Colonial Order: White Supremacy and Black Resistance in the Eastern Cape 1770-1865, Cambridge, 1992; Mahmood Mamdani, Citizen and Subject: Contemporary Africa and the Legacy of Late Colonialism, Princeton, 1996.

2 Charles Manning Clark, A History of Australia, Vol. Three, The Beginning of an Australian Civilization 1824-1851, Melbourne, 1973.

3 George Cockburn Henderson, Sir George Grey, Pioneer of Empire in Southern Lands, London, 1907.

4 'Grey, Sir George', in Leslie Stephen and Sidney Lee, eds, Dictionary of National Biography (DNB): From the Earliest Times until 1900, Vol.22 Supplements, p.786. 


\section{Journal of New Zealand Studies}

See bottom of left column for the initials 'W.P.R.'. Available online in the (Oxford) DNB Archive at http://www.oxforddnb.com/view/olddnb/11534.

5 A.H. McLintock, Crown Colony Government in New Zealand, Wellington, 1958.

6 B.J. Dalton, War and Politics in New Zealand 1855-1870, Sydney, 1967.

7 Forthcoming, Penguin.

8 David Hamer, The New Zealand Liberals: The Years of Power, 1891-1912, Oxford, 1988; Mark Francis, Governors and Settlers: Images of Authority in the British Colonies 1820-1860, Basingstoke, 1992; Matthew Palmer, The Treaty of Waitangi and the New Zealand Constitution, Wellington, 2008.

9 John Pocock, The Machiavellian Moment: Florentine Political Thought and the Atlantic Republican Tradition, Princeton, 1975.

10 Richard Whately, Account of an Expedition to the Interior of New Holland, edited by Lady Mary Fox, London, 1837.

11 Thomas Arnold, The Effects of Distant Colonization on the Parent State: A Prize Essay Recited in the Theatre at Oxford June 7 1815, Oxford, 1815.

12 Thomas Arnold, Introductory Lectures on Modern History delivered in Lent Term MDCCCXLII with the Inaugural Lecture delivered in December MDCCCXLI, London 1874.

13 James Anthony Froude, Oceana, or, England and her Colonies, London, 1886.

14 George Cornewall Lewis, in Charles Prestwood Lucas, ed., An Essay on the Government of Dependencies, Oxford, 1891.

15 Richard Brent, Liberal Anglican Politics: Religion, Whiggery and Reform 1830-1841, Oxford, 1987.

16 Hugh Trevor-Roper, The Crisis of the Seventeenth Century: Religion, Reformation and Social Change, New York, 1968.

17 Bishop Joseph Butler, The Analogy of Religion, Natural and Revealed, or the Constitution and Course of Nature, Aberdeen, 1775.

18 Adam Smith, An Inquiry into the Nature and Causes of the Wealth of Nations, Dublin, 1785.

19 Albert Gallatin, A Synopsis of Indian Tribes within the United States East of the Rocky Mountains and in the British and Russian Possessions in North America, [1836], New York, 1973.

20 Pocock.

21 Hugo Grotius, De Belli ac Pacis Libri Tres; in Quibus Jus Naturae et Gentium, item Juris Praecipua Explicantur, Amsterdam, 1689.

22 Gilles Deleuze and Felix Guattari, Les Editions de Minuit, Paris, 1980. I wonder if they took this from the discussion on Grey in Charles-André Julien's Les Techniciens de la Colonisation (XIXe-XXe siècles), (Paris, 1947).

23 Mark Hickford, 'Making Territorial Rights of the Natives: Britain and New Zealand 1830- 1847', D.Phil. thesis, University of Oxford, 1999.

24 Sir William Johnson (1717-1774) was the Superintendent of the Appalachian Protectorate and the developer and exponent of native protection policy.

25 Edmund Spenser, A View of the State of Ireland, Written by Way of Dialogue between Eudoxus and Irenaeus, Dublin, 1763. 


\section{Political Thought and Constitutionalism of Sir George Grey}

26 Arnold, The Effects of Distant Colonization. See also, Robert Johnson, The New Life of Virginea: Declaring the Former Successe and Present Estate of that Plantation, Being the Second Part of Nova Britannia, London, 1612.

27 William L. Rees, From Poverty to Plenty; or the Labour Question Resolved, London, 1888 .

28 John Davison, An Inquiry into the Origin and Intent of Primitive Sacrifice and the Scripture Evidence Respecting it; with Observations on the Opinions of Spencer, Bishop Warburton, Archbishop Magee and other writers on the same subject; and some reflections on the Unitarian Controversy, London, 1825. This work delivers a blast at the Liberal Anglicans right from the Oriel Common Room, which was one of their headquarters.

29 'Philo-Indicus', Gentleman's Magazine, XXXIV, 1763.

30 In A.R. Chisholm and J.J. Quinn, eds, Verse of Christopher Brennan, Sydney, 1960, p.102. 
Journal of New Zealand Studies 